\title{
An Exploratory Study to Understand the Scope of Privately Managed Elementary Schools in India
}

\author{
Pulak Das ${ }^{1, *}$ \\ ${ }^{1}$ Human Resource Group, Indian Institute of Management Calcutta, Joka, Kolkata 700104, \\ India \\ *Correspondence: Tel: 91-33-2467-8300. E-mail: pulak@iimcal.ac.in
}

Received: January 27, 2014 Accepted: March 3, 2014 Published: March 24, 2014

doi:10.5296/ije.v6i1.4991ＵRL: http://dx.doi.org/10.5296/ije.v6i1.4991

\begin{abstract}
This study attempted to understand if at the national aggregate level Indian households' preferences for their children's school level education were shifting from Government to privately managed schools and whether such privatised schooling was scalable for mass education required for accelerated diffusion of elementary education across the country. Based on time series data on the numbers of schools and their enrolments over the period from 1993-94 to 2007-08, the study found both the number of schools and their enrolments increased abruptly around year 2000-01 when mission mode programme of "Sarva Shikhsa Abhiyan" was launched, indicating a change in environment and strong supply side impact On the growth of student enrolments in elementary schools. Analysis of student enrolments in Government and in privately managed schools indicated growing households' preferences for privately managed schools. However, though in terms of households' choices, demands for privately managed schools were growing yet for faster diffusion of elementary education across the country, privately managed elementary schools did not turn out a good substitute to low cost Government managed schools. At the total national aggregate level the market for elementary education showed the prospects of high growth with simultaneous presence of a collective learning environment for the population and a low private cost based learning system for the individual at household level. It appears faster progress towards raising the enrolment ratio of Indian children in elementary schools which has been abysmally low for so many years, could be achieved by adopting more innovative approach towards their finance and governance.
\end{abstract}

Keywords: privatization; collective learning; mission mode programme; Sarva Shiksha Abhiyan; decentralization 


\section{Introduction}

In India, the Governments at the centre and the states have been the principal providers of education services for many years. However, though overtime the Government poured a lot of resources for increasing the enrolment of children in schools yet the difference between the potential and the actual enrolment was never insignificant. In year 2007-08, the estimated numbers of children in the age group of 6 years to 10 years were 119 millions (Selected Educational Statistics: 2007-08). However, according to $64^{\text {th }}$ round of National Sample Survey, only $84 \%$ or 100 million of them were actually in school and the rest 19 millions were not enrolled in any school. Collectively the projected numbers of children and youths in the age group of 6 years to 17 years who were eligible to study in a school in one of the twelve grades from Grade I to Grade XII were 289 millions. Out of that huge number of potential learners only 176 millions were actually in school and the rest 113 millions were not enrolled in any school (Government of India, 2010).

For bringing more number of children into the classrooms of elementary schools, in year 2000-01 Government of India launched a very well publicized and well funded mission mode programme titled "Sarva Shiksha Abhiyan" (SSA) or "Education for all” (Government of India, New Delhi 2000). It was a ten years long target oriented education programme whose main goal was to take the elementary school level learning closer to the homes of the learners living in different parts of India by building lot more new Primary and Middle schools both by the states as well as in-cooperation with social non-Governmental organizations. Along with building of new schools lot many new teachers were also appointed to run those schools.

In the present study we wanted to see if at the national aggregate level Indian households' preferences for their children's school level education were shifting from Government to privately managed schools and whether such privatised schooling was scalable for mass education required for accelerated diffusion of elementary education across the country.

\section{Decentralized Education: A Conceptual Framework}

During much of the last century, except in a few developed countries most countries followed a highly centralized state managed education system. A few of the important advantages of centralized delivery of education services are economy of scale in delivery cost, policy and programme uniformity and consistency in personnel management and administration across locations. A centralized program design and delivery also ensure uniformity in learning goal and curriculum structure across different locations when professional competencies of teachers and administrators are not very high (Winkler, 1993).

Toward the end of last century both under increasing need for economic integration as well as for political reasons of getting more involvement of users of services and giving them more voices in the way those services are designed and delivered, many countries started liberalizing their education from the state control. Hanson (1998) suggested a country's educational decentralization could be one of the following three forms or a mixture of them. viz. (1) de-concentration that involve transfer of tasks and works to other units but not the 
authority; (2) delegation that involve transfer of decision making power to hierarchically lower levels; (3) devolution of authority to lower levels where staff in selected areas could take action without consulting the higher authority. In this classification of decentralization processes, privatisation of education is closer to devolution of authority to non-Governmental entities on certain areas.

Over the period from 1980 to 2000, different political regimes of Chile tried varieties of education systems including private schools with state distributed education voucher to parents (Schiefelbein \& Schiefelbein, 2000). Since their coming to power in 1949 Chinese Governments tried various forms and mixtures of centralized and decentralized forms of education (Hawkins, 2000). Economic reform and market forces have influenced the education processes of mainland China very heavily and now privatised education plays quite an important role particularly in higher education (Mok, 1999). In late nineteenth century Japan had a highly centralized education system which went for fully deregulated system following Second World War. But after 1956, the Japanese Government re-established its control over the schools by prescribing standard education curriculum for all schools (Muta, 2000). Tang \& Bray (2000) described the evolution of education systems of Hong-Kong from a highly centralized system in early twentieth century to a completely decentralized system in late twentieth century. Mexican Government went for decentralized education system in late 1980s when it found its existing centralized systems very inefficient, rigid and unresponsive to the needs of local schools (Ornelas, 2000).

Lo \& Gu (2008) compared the decentralization of school management in Taiwan and South Korea and found that decentralization processes of these two countries could be classified into two categories viz. managerial and societal. For Taiwan they found decentralization was well grounded with adequate empowerment of teachers and parents but that in South Korea the institutional structures for decentralization were far from satisfactory.

There have been a number of studies on the efficiencies and effectiveness of state and privately managed school systems. Based on survey of teachers, principals and members of school boards in Nigeria, Ikoya (2008) found most respondents felt that decentralized management of school infrastructure was more efficient and effective as it ensured better accountability and reduced corruption in school management. In India much of the educational decentralization were more like the third type of Hanson's classification where different types of private entities were allowed to run their own schools using the educational curriculum decided by a central authority called the education board. In 1993-94, out of 570455 running primary schools, only $4.1 \%$ schools were run as pure privately managed schools which received no aid from anywhere. There have been a few studies on the comparative performance of privately and Government managed schools in India. And, most of them found overall academic performance of students from privately managed schools were better than those who studied in Government managed schools. Kingdon (1996) found the cost-efficiencies of Government managed schools in India were comparable with Government aided privately managed schools but their quality efficiencies were well below those of privately managed unaided schools. Goyal (2007) found the average performance of students from Government schools in Rajasthan state of India were well below those who 
were studying in privately managed schools. However, there have been few studies to understand the scalability of existing privatised education models for faster diffusion of early education in a big, socially heterogeneous, and only moderately industrialized country like India where a large percentage of population still live a bare subsistence life. The main motive of the present study is to understand this scalability of the Indian privatized education processes.

\section{Environment of School Level Learning in India}

\subsection{Academic Governance of Indian Schools}

Academic Governance of Indian school level education is highly centralized where the course curriculum and its sequences are set by different education boards operating either at central or at individual state level. Over and above the curriculum, every school board also set guidelines on a school's physical and human infrastructural requirements. Though, in practice these rules on infrastructure are more often followed in breach than in compliance (Dixon \& Tooley, 2005)!

The total school level learning in India could be divided into four stages viz. a Primary stage from Grade I to Grade V, a Middle school or upper Primary stage of three years from Grade VI to Grade VIII followed by a Secondary stage of two years of Grade IX to Grade X. The final stage of school level learning has two years from Grade XI to Grade XII often called the Senior Secondary stage. Collectively the learning from Grade-I to Grade-VIII is sometime described as the elementary education level.

\subsection{Administrative Governance of Indian Schools}

Educational regulations of India allowed the Central Government, various State Governments, local municipalities, social welfare organizations, religious trusts, business trusts, privately formed management committees, individual entrepreneurs as well as business corporations to build and operate schools. In India, most Government schools are actually built and managed by the various state Governments. At the state Government levels three forms of delegations of authorities were noted. Some schools are under direct control of the state Governments where a school's principal and teachers are all part of the common Government administrative machinery. These are fully centralised schools with least authority given to the school principals beyond the daily operational matters of scheduling of classes. There are some schools which are overseen by municipalities, zilla parisads (District level elected bodies) and village panchayets (Village level elected bodies). These schools receive financial grants from the Government by way of budgetary allocation but the Government does not enquire or interfere on the way those monies are spent. These schools are known as local body managed schools. There are schools built by a group of socially oriented individuals called management committee. These are ad-hoc committees comprising of volunteers who decided to build and run a school as a non-profit organization. These schools receive occasional financial grants from the Government. But Government does not interfere in their day to day activities neither do they demand any record on how they spend the grant. These 
are semi-private schools where local management committee has full control over both financial and operational matters. In Government documents these schools are described as privately managed aided schools. In addition to these three types of schools, there is a fourth category of schools called privately managed unaided schools which are built by private entrepreneurs or business corporations and run by teachers appointed by them. These schools are fully autonomous on administrative matters and have full authority to hire and fire teachers and staff to meet financial, administrative and academic goals.

The private expenditure of a student varied widely from school to school depending on whether a school was a direct Government run, a local body managed, a privately managed Government aided or a pure privately managed school which received no financial support from the Government. In 2007 the average yearly private expenditure of a student was $\$ 9.46$, \$10.42, \$62.74 and \$83.5 for studying in a direct Government managed, in local body managed, in a privately managed Government aided schools and in a privately managed unaided Primary schools respectively (1\$ equals Rs50 assumed). These private costs for education increase as one moves up from Primary stage to Middle, to Secondary and to Senior Secondary stages respectively (Government of India, 2010).

\section{Date Sources}

The present study was based on data collected by the Ministry of Human Resource Development, Government of India and by the National Institute of Educational Planning and Administration, Government of India.

\section{Results}

\subsection{Launch of "SSA" Programme and change in Environment of Primary and Middle schools}

Figure 1 and Figure 2 showed the changing numbers of Primary and Middle schools and their total student enrolments over the period from 1993-94 to 2007-08 respectively. From Figure 1 and Figure 2, it could be seen that both the number of schools and their enrolments jumped around the year 2000-01 when "SSA" programme was launched. It was to be noted from Figure 2 that enrolment in Primary schools jumped up from the trend line in 2001-02 while the number of Primary schools jumped up from the trend line one year later only in 2002-03. Such spurt in enrolment even before much actions happened in the supply side of school level learning was symptomatic of significant change in the learning environment of elementary schools heralded by the launch of mission mode programme of "SSA". 


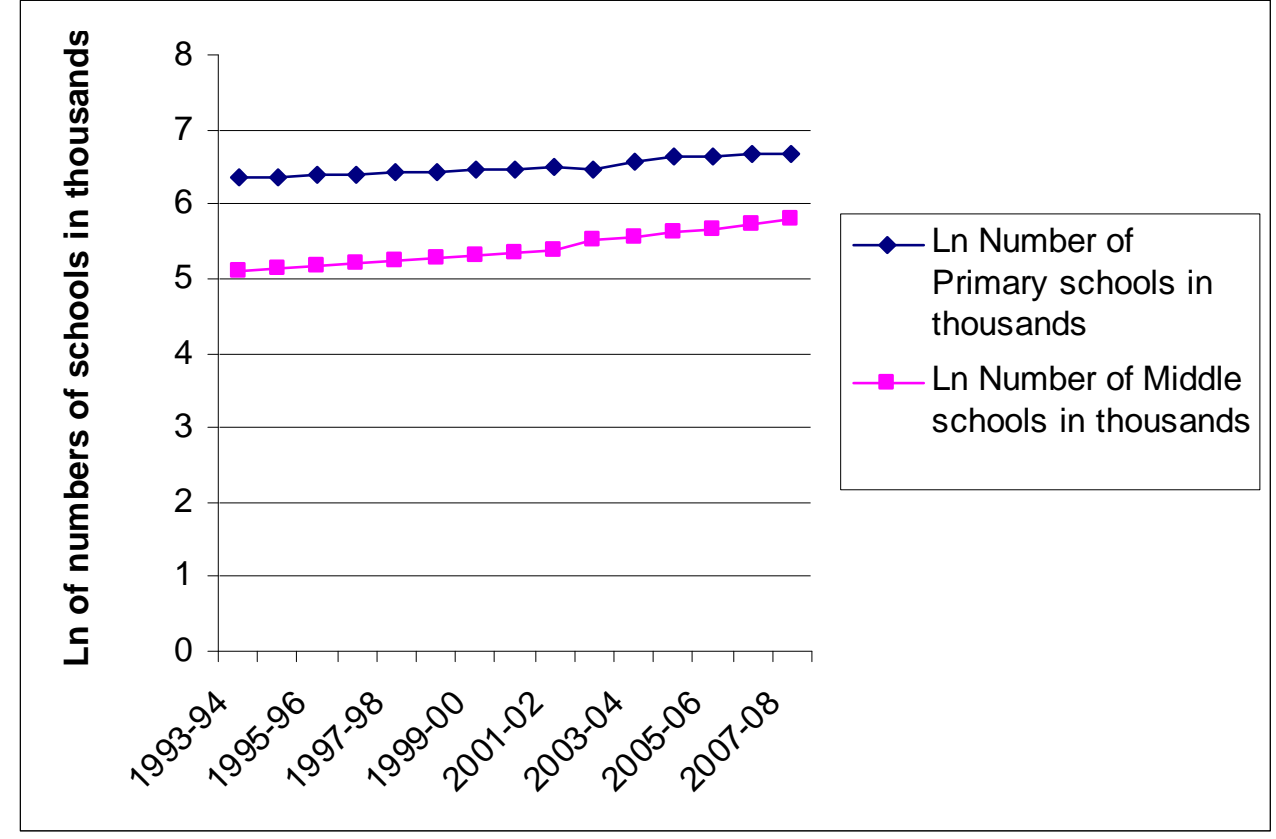

Figure 1. Growth of Numbers of Primary and Middle Schools over time from 1993-94 to 2007-08

Data sources:

Selected Educational Statistics: 2005-06, All India, Time-Series;

Selected Educational Statistics: 2006-07 State-wise, All Tables;

Selected Educational Statistics: 2007-08.

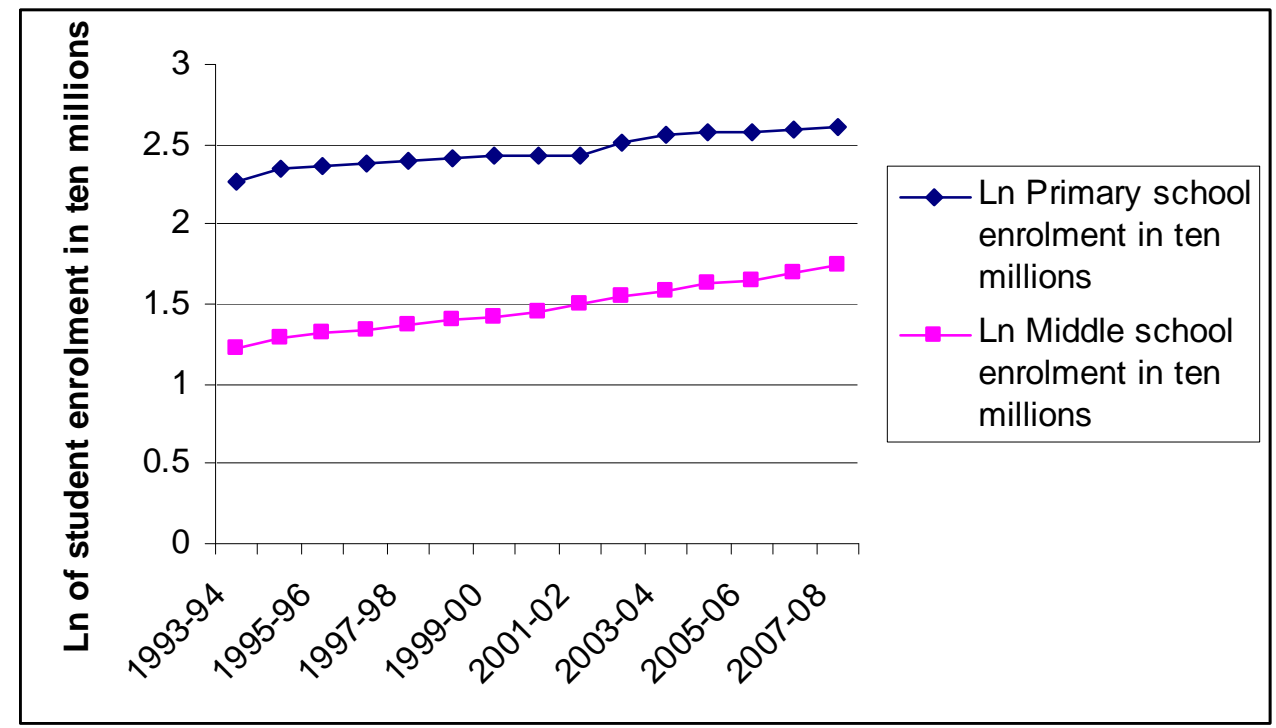

Figure 2. Growth of Numbers of Enrolled Students in Primary and Middle Schools over time from 1993-94 to 2007-08

Data sources:

Selected Educational Statistics: 2005-06, All India, Time-Series;

Selected Educational Statistics: 2006-07 State-wise, All Tables; 


\section{Macrothink}

Selected Educational Statistics: 2007-08.

5.2 Launch of "SSA" Programme and Change in Average Annual Growth Rates of Numbers of Primary and Middle Schools and their Student Enrolments

Table 1 showed the estimated growth equations of numbers of Primary and Middle schools and their student enrolments over the period from 1993-94 to 2007-08. To capture the effects of launch of "SSA" programme on the shift of the growth curves a dummy (0-1) variable where 1 corresponded with the period after the launch of "SSA" programme and " 0 " otherwise was used as an additional regressor. Equation (1) of Table 1 showed that over the period from 1993-94 to 2000-01 i.e. the period before the launch of "SSA" programme, the number of Primary schools in the country grew at an average annual rate of $2.07 \%$. And, from 2000-01 to 2007-08 i.e. after the launch of "SSA" programme the number of Primary schools grew at an average annual rate of 3.44\%. On the other hand, Equation (2) of Table 1 showed that from 1993-94 to 2000-01 i.e. the period before the launch of "SSA" programme, the number of enrolled students in Primary schools grew at an average rate of $2.2 \%$ per annum. And, there was no significant change in this growth rate of enrolled students of Primary schools even after the launch of the "SSA" programme.

Equations (3) and (4) of Table 1 showed the estimated growth equations of numbers of Middle schools and their student enrolments over the period from 1993-94 to 2007-08 respectively. From these equations it could be seen that from 1993-94 to 2000-01 i.e. the period before the launch of "SSA" programme number of Middle schools grew at an average annual rate of $3.53 \%$ which jumped to an average annual rate of $6.39 \%$ after the launch of "SSA" programme. On the other hand before the launch of "SSA" programme the student enrolments in Middle schools grew at an average annual rate of $3 \%$ which increased to an average annual rate of $4 \%$ after the launch of the "SSA" programme i.e. the period from 2000-01 to 2007-08. This showed that the number of Middle schools grew at a much faster rate than that of the number of students both before and after the launch of "SSA" programme. 
Table 1. Estimated growth equations of total numbers of Primary and Middle schools and their enrolments over the period from 1993-94 to 2007-08

\begin{tabular}{|c|c|c|c|c|}
\hline \multirow{2}{*}{$\begin{array}{l}\text { Independent } \\
\text { Variables }\end{array}$} & \multirow[b]{2}{*}{$\begin{array}{l}\text { Primary schools } \\
\text { Dependent } \\
\text { variable: Log of } \\
\text { numbers of } \\
\text { Primary schools }\end{array}$} & \multirow[b]{2}{*}{$\begin{array}{l}\text { Dependent } \\
\text { variable: Log of } \\
\text { Primary school } \\
\text { Enrolment in } \\
\text { millions }\end{array}$} & \multicolumn{2}{|l|}{ Middle schools } \\
\hline & & & $\begin{array}{l}\text { Dependent } \\
\text { variable: Log of } \\
\text { numbers of } \\
\text { Middle schools }\end{array}$ & $\begin{array}{l}\text { Dependent } \\
\text { variable: Log } \\
\text { of Middle } \\
\text { school } \\
\text { enrolment in } \\
\text { millions }\end{array}$ \\
\hline No & (1) & (2) & (3) & (4) \\
\hline Intercept & 13.254 & 4.61 & 11.998 & 3.551 \\
\hline $\begin{array}{l}\text { Time in } \\
\text { years }\end{array}$ & $\begin{array}{l}0.0207 \\
(4.66)^{* * * *}\end{array}$ & $\begin{array}{l}0.022 \\
(5.138) * * * *\end{array}$ & $\begin{array}{l}0.0353 \\
(11.64)^{* * * *}\end{array}$ & $\begin{array}{l}0.030 \\
(14.49)^{* * *}\end{array}$ \\
\hline $\begin{array}{l}\text { Dummy } \\
\text { variable } \\
(0-1)\end{array}$ & $\begin{array}{l}-0.1289 \\
(3.05)^{* * *}\end{array}$ & $\begin{array}{l}-0.058 \\
(1.38)^{*}\end{array}$ & $\begin{array}{l}-0.189 \\
(6.59)^{* * * *}\end{array}$ & $\begin{array}{l}-0.07 \\
(3.6)^{* * *}\end{array}$ \\
\hline $\begin{array}{l}\text { Dummy } \\
\text { variable } \mathrm{x} \\
\text { Time in } \\
\text { years }\end{array}$ & $\begin{array}{l}0.0137 \\
(2.39)^{* *}\end{array}$ & $\begin{array}{l}0.005 \\
(0.838)\end{array}$ & $\begin{array}{l}0.0286 \\
(7.33) * * * *\end{array}$ & $\begin{array}{l}0.01 \\
(3.92)^{* * * * *}\end{array}$ \\
\hline $\mathrm{R}^{2}$ & 0.965 & 0.96 & 0.996 & 0.996 \\
\hline $\begin{array}{l}\text { Number of } \\
\text { observations }\end{array}$ & 15 & 15 & 15 & 15 \\
\hline
\end{tabular}

Selected Educational Statistics: 2005-06, All India, Time-Series;

Selected Educational Statistics: 2006-07 State-wise, All Tables;

Selected Educational Statistics: 2007-08.

5.3 Launch of "SSA" programme and change in numbers of Primary schools run by different managements and their student enrolments

Due to non-availability of good time series data on numbers of Primary and Middle schools run by different managements and their student enrolments, regression estimation of growth equations for numbers of schools under different managements and their student enrolments were not attempted. Instead, we compared the numbers of new schools launched by different managements and the corresponding change in student enrolments over two periods of three years each from 2001-02 to 2004-05 and 2004-05 to 2007-08 respectively. The year 2004-05 
was chosen as an intervening year to understand the effects if any of the change of political set up in Indian central Government following the national election on the tempo of "SSA" implementation. Though, officially the newly elected Government of India which came to power in 2004-05 did not abandon the "SSA" programme completely but for increasing student enrolments in Primary and Middle schools of the country, the priorities and approach of the new Government were significantly different from the political party that was there in power before them.

Table 2 showed the numbers of Primary schools run by different managements and their student enrolments in years 2001-02, 2004-05 and 2007-08 respectively (Data related to direct Government and local body managed schools were combined to make one common category of direct Government managed schools). From this table it could be seen that between 2001-02 and 2004-05, total number of Primary schools in the country increased by 103479 schools or $15.6 \%$ over their numbers in 2001-02. Out of the 103479 new schools, 88634 new Primary schools were due to increasing number of new Primary schools launched and managed as direct Government managed schools and the rest 14845 schools were due to increase in the number of privately managed schools. This showed that between year 2001-02 and 2004-05, the Government managed schools dominated the market for providing Primary school facilities to most of the new Primary school students who joined the school level learning process after 2001-02. The student enrolment of year 2004-05 indicated, as much as 80.9\% of the Primary school students of year 2004-05 were enrolled in direct Government managed schools.

In contrast to the period from years 2001-02 and 2004-05 when as many as 103479 new Primary schools were launched, over the period from 2004-05 to 2007-08 the number of such new Primary schools dropped to just 20307 or just the 2.6\% of their numbers in 2004-05. Further, unlike the period from 2001-02 to 2004-05 when much of the new Primary schools were due to launch of new schools by the Government directly, the entire growth of the number of Primary schools in the period from 2004-05 to 2007-08 was due to launching and managing the new Primary schools by the private managements. Between years of 2004-05 and 2007-08, the number of privately managed Primary schools increased by 29405 of which 25807 or $87.8 \%$ were on account of increase in number of privately managed aided Primary schools.

On the effect of growth of number of schools on the enrolment of students, Table 2 showed that from 2001-02 to 2004-05, the number of enrolled students in Primary schools increased by 16.9 millions. In contrast during the next three years of 2004-05 to 2007-08, the number of enrolled students increased only by 4.7 millions. This showed that significant growth and decline in enrolment of students in Primary schools over the periods from 2001-2 to 2004-05 and from 2004-05 to 2007-08 coincided with the periods of high and low growth of number of Primary schools. This was indicative of strong supply side effects on student enrolments in Primary schools.

Further, over the period from 2004-05 to 2007-08, it was not just the decline in absolute number of students that was significant, the distribution of students between Government and 
privately managed schools also changed. In 2004-05, out of 130.8 millions enrolled students of Primary schools about $81 \%$ were in Government managed schools while the rest $19 \%$ were in privately managed schools. But in 2007-08, this distribution changed to $75.4 \%$ in Government managed schools and $24.6 \%$ in privately managed schools. This distribution was more skewed in favour of privately managed schools among those who joined the primary schools after 2004-05. All the $100 \%$ of the 4.7 millions increased student enrolments of Primary schools of year 2007-08, was on account of increased enrolment in privately managed Primary schools. This showed over time households' preferences for privately managed schools were rising fast.

It was to be noted in Table 2 that average enrolment per school of privately managed Primary schools was much higher than that of the Government managed schools. In year 2007-08, the average enrolment per school of Government managed Primary schools was about 149 students per school while that of privately managed Primary schools it was 318 students per school. This was indicative of higher efficiencies of using physical and human infrastructures by the privately managed schools than that by the Government managed schools.

Table 2. Numbers of Primary schools under different management and their student enrolments in 2001-02, 2004-05 and 2007-08 and their changes over the periods of 2001-02 to 2004-05 and 2004-05 to 2007-08

\begin{tabular}{|c|c|c|c|c|c|c|}
\hline \multirow{2}{*}{$\begin{array}{l}\text { Number of Schools/ } \\
\text { Number of Enrolled } \\
\text { students }\end{array}$} & \multirow[t]{2}{*}{ Management types } & \multicolumn{3}{|c|}{ Numbers in years } & \multirow{2}{*}{$\begin{array}{l}\text { Change } \\
\text { over the } \\
\text { period from } \\
2001-02 \text { to } \\
2004-05\end{array}$} & \multirow[b]{2}{*}{$\begin{array}{l}\text { Change over } \\
\text { the period } \\
\text { from } \\
2004-05 \text { to } \\
2007-08\end{array}$} \\
\hline & & 2001-04 & 2004-05 & 2007-08 & & \\
\hline \multirow[t]{5}{*}{ Number of schools } & All & 664041 & 767520 & 787827 & 103479 & 20307 \\
\hline & $\begin{array}{l}\text { Direct Government } \\
\text { managed schools }\end{array}$ & $\begin{array}{l}603746 \\
(90.9)\end{array}$ & $\begin{array}{c}692380 \\
(90.2)\end{array}$ & $\begin{array}{c}683282 \\
(86.7)\end{array}$ & $\begin{array}{l}88634 \\
(85.6)\end{array}$ & -8998 \\
\hline & $\begin{array}{l}\text { Privately managed } \\
\text { aided and unaided } \\
\text { schools together }\end{array}$ & $\begin{array}{l}60295 \\
(9.08)\end{array}$ & $\begin{array}{l}75140 \\
(9.78)\end{array}$ & $\begin{array}{l}104545 \\
(13.3)\end{array}$ & $\begin{array}{l}14845 \\
(14.4)\end{array}$ & $\begin{array}{l}29405 \\
(145)\end{array}$ \\
\hline & $\begin{array}{l}\text { Privately managed } \\
\text { aided schools }\end{array}$ & $\begin{array}{l}20386 \\
(33.8)\end{array}$ & $\begin{array}{l}19572 \\
(26.1)\end{array}$ & $\begin{array}{l}45379 \\
(43.4)\end{array}$ & -814 & $\begin{array}{l}25807 \\
(87.8)\end{array}$ \\
\hline & $\begin{array}{l}\text { Privately managed } \\
\text { unaided schools }\end{array}$ & $\begin{array}{l}39909 \\
(66.2)\end{array}$ & $\begin{array}{l}55568 \\
(73.9)\end{array}$ & $\begin{array}{l}59166 \\
(56.6)\end{array}$ & $\begin{array}{l}15660 \\
(105.5)\end{array}$ & $\begin{array}{c}3597 \\
(12.2)\end{array}$ \\
\hline \multirow[t]{3}{*}{$\begin{array}{l}\text { Number of Enrolled } \\
\text { students in millions }\end{array}$} & All & $\begin{array}{l}113.9 \\
\{171\}\end{array}$ & $\begin{array}{l}130.8 \\
\{170\}\end{array}$ & $\begin{array}{l}135.5 \\
\{172\}\end{array}$ & $\begin{array}{c}16.9 \\
\{163\}\end{array}$ & $\begin{array}{c}4.7 \\
\{231\}\end{array}$ \\
\hline & $\begin{array}{l}\text { Direct Government } \\
\text { managed schools }\end{array}$ & & $\begin{array}{l}105.8 \\
(80.9) \\
\{153\}\end{array}$ & $\begin{array}{l}102.18 \\
(75.4) \\
\{149\}\end{array}$ & & -3.64 \\
\hline & $\begin{array}{l}\text { Privately managed } \\
\text { aided and unaided } \\
\text { schools together }\end{array}$ & & $\begin{array}{l}24.9 \\
(19.1) \\
\{332\}\end{array}$ & $\begin{array}{l}33.32 \\
(24.6) \\
\{318\}\end{array}$ & & $\begin{array}{l}8.38 \\
(178) \\
\{285\}\end{array}$ \\
\hline
\end{tabular}

( ) Percentage of total; $\{\quad\}$ Average number of students per school 
Data sources:

Selected Educational Statistics: MHRD, 2004-05;

Selected Educational Statistics: 2005-06, All India, Time-Series;

Selected Educational Statistics: 2006-07 State-wise, All Tables;

Selected Educational Statistics: 2007-08;

Analytical Tables 2004-05;

Analytical Tables 2007-08.

5.4 Launch of "SSA" programme and change in numbers of Middle schools run by different managements and their student enrolments

Table 3 showed the total numbers of Middle schools under different managements and their student enrolments in years of 2001-02, 2004-05 and 2007-08 respectively. From this table it could be seen that from 2001-02 to 2004-05, the number of Middle schools increased by 55105. Out of the increase of 55105 Middle schools for the period from 2001-02 to 2004-05, 30518 or $55.4 \%$ Middle schools were launched and managed by Governments directly while the rest 24587 or $44.6 \%$ were run as privately managed Middle schools. Again among the newly launched privately managed Middle schools of the period from 2001-02 to 2004-05, 24130 or $98 \%$ schools were launched and managed as privately managed unaided Middle schools.

From years 2004-05 to 2007-08, the number of Middle schools increased by 50443 schools of which 40986 or $81.2 \%$ were due to launching of new Middle schools as direct Government managed schools while the rest 9457 or $18.7 \%$ were due to increase in number of privately managed Middle schools. Between years 2004-05 to 2007-08, a total 12631 new Middle schools were launched as privately managed aided schools while the number of Privately managed unaided schools went down by 3174. This showed unlike the virtual withdrawal of the state administrations in launching and managing new schools in Primary school space after year 2004-05, there was no sign of reduced tempo of the Governments for launching and managing schools in the Middle school space.

On the student enrolment front, Table 3 showed that from years 2001-02 to 2004-05, the Middle school student enrolments increased by 6.4 millions while that over the period from 2004-05 to 2007-08, the Middle schools enrolments increased only by 6 millions. This showed that unhindered growth of number of Middle schools over the period from 2004-05 to 2007-08 ensured the pace of growth of student enrolments of Middle schools undisturbed. Further out of the 6 millions of increased student enrolments of Middle schools, 1.8 millions or 29.8\% were enrolled in Government managed schools while the rest 4.2 millions or $69.2 \%$ were in privately managed Middle schools. Though, out of all the newly launched Middle schools of the period from 2004-05 and 2007-08 only 18.74\% of the newly launched Middle schools were privately managed schools. This showed like in the Primary school stage, households' preferences for placing their children in privately managed Middle schools were 
also rising with time.

It was to be noted from Table 3 that like in Primary schools, over the period from 2001-02 to 2007-08 the average enrolment per school of privately managed Middle schools was much higher than that of the Government managed Middle schools. Further, over time this average number of students per schools for privately managed Middle schools was rising while that of the Government managed Middle schools it was falling. From 2004-05 to 2007-8, the average student enrolment per school of Government managed Middle schools dropped from 173 to 152 while that of privately managed Middle schools it rose from 222 to 246.

Table 3. Numbers of Middle schools under different management and their student enrolments in 2001-02, 2004-05 and 2007-08 and their changes over the periods of 2001-02 to 2004-05 and 2004-05 to 2007-08

\begin{tabular}{|c|c|c|c|c|c|c|}
\hline \multirow{2}{*}{$\begin{array}{l}\text { Number } \\
\text { of } \\
\text { Schools/ } \\
\text { Number } \\
\text { of }\end{array}$} & \multirow[t]{3}{*}{ Management types } & \multicolumn{3}{|c|}{ Numbers in years } & \multirow{2}{*}{$\begin{array}{l}\text { Change } \\
\text { over the } \\
\text { period } \\
\text { from }\end{array}$} & \multirow{2}{*}{$\begin{array}{l}\text { Change } \\
\text { over the } \\
\text { period } \\
\text { from } \\
\text { 2004-05 }\end{array}$} \\
\hline & & 2001-04 & $2004-05$ & $2007-08$ & & \\
\hline $\begin{array}{l}\text { Enrolled } \\
\text { students }\end{array}$ & & & & & $\begin{array}{c}\text { to } \\
2004-05\end{array}$ & $\begin{array}{c}\text { to } \\
2007-08\end{array}$ \\
\hline $\begin{array}{l}\text { Number } \\
\text { of }\end{array}$ & All & 219626 & 274731 & 325174 & 55105 & 50443 \\
\hline schools & $\begin{array}{l}\text { Direct Government } \\
\text { managed schools } \\
\text { Privately managed } \\
\text { aided and unaided } \\
\text { schools together }\end{array}$ & $\begin{array}{l}167838 \\
(76.4) \\
51788 \\
(23.58)\end{array}$ & $\begin{array}{l}198356 \\
(72.2) \\
76375 \\
(27.8)\end{array}$ & $\begin{array}{l}239342 \\
(73.6) \\
85832 \\
(26.4)\end{array}$ & $\begin{array}{l}30518 \\
(55.4) \\
24587 \\
(44.6)\end{array}$ & $\begin{array}{l}40986 \\
(81.2) \\
9457 \\
(18.7)\end{array}$ \\
\hline & $\begin{array}{l}\text { Privately managed } \\
\text { aided schools }\end{array}$ & $\begin{array}{l}17153 \\
(33.1)\end{array}$ & $\begin{array}{l}17610 \\
(23.1)\end{array}$ & $\begin{array}{l}30241 \\
(35.2)\end{array}$ & $\begin{array}{c}457 \\
(1.87)\end{array}$ & $\begin{array}{c}12631 \\
(133.5)\end{array}$ \\
\hline & $\begin{array}{l}\text { Privately managed } \\
\text { unaided schools }\end{array}$ & $\begin{array}{l}34635 \\
(66.9)\end{array}$ & $\begin{array}{l}58765 \\
(76.9)\end{array}$ & $\begin{array}{l}55591 \\
(64.8)\end{array}$ & $\begin{array}{l}24130 \\
(98.1)\end{array}$ & -3174 \\
\hline $\begin{array}{c}\text { Number } \\
\text { of }\end{array}$ & All & $\begin{array}{c}44.8 \\
\{204\}\end{array}$ & $\begin{array}{c}51.2 \\
\{186\}\end{array}$ & $\begin{array}{c}57.2 \\
\{176\}\end{array}$ & $\begin{array}{c}6.4 \\
\{116\}\end{array}$ & $\begin{array}{c}6 \\
\{119\}\end{array}$ \\
\hline $\begin{array}{l}\text { Enrolled } \\
\text { students } \\
\quad \text { in } \\
\text { millions }\end{array}$ & $\begin{array}{l}\text { Direct Government } \\
\text { managed schools }\end{array}$ & & $\begin{array}{l}34.3 \\
(67.0) \\
\{173\}\end{array}$ & $\begin{array}{c}36.1 \\
(63.06) \\
\{152\}\end{array}$ & & $\begin{array}{c}1.8 \\
(29.8) \\
\{51\}\end{array}$ \\
\hline & $\begin{array}{l}\text { Privately managed } \\
\text { aided and unaided } \\
\text { schools together }\end{array}$ & & $\begin{array}{l}16.9 \\
(33.1) \\
\{222\}\end{array}$ & $\begin{array}{l}21.1 \\
(36.9) \\
{[246\}}\end{array}$ & & $\begin{array}{c}4.2 \\
(69.2) \\
\{441\}\end{array}$ \\
\hline
\end{tabular}

( ) Percentage of total; $\{\quad\}$ Average number of students per school 
Data sources:

Selected Educational Statistics: MHRD, 2004-05;

Selected Educational Statistics: 2005-06, All India, Time-Series;

Selected Educational Statistics: 2006-07 State-wise, All Tables;

Selected Educational Statistics: 2007-08;

Analytical Tables 2004-05;

Analytical Tables 2007-08.

\section{Discussion and Implications}

Our analysis of changing numbers of Primary and Middle schools and their student enrolments over the period from 1993-94 to 2007-08 indicated a sign of significant change in elementary school level learning environment in India immediately after the launch of "SSA" programme. This was indicative of presence of high level latent demands for elementary education in India even before the "SSA" programme was launched. "SSA" programme and its various administrative initiatives including a nationwide state sponsored media campaign and ground level actions for involving volunteers and non-Governmental organizations for building more number of schools across villages and towns brought those latent demands on the surface. These were the demands by those households who could not turn their wishes and aspirations for their children's schooling into economic transactions due to non-availability of any school near their homes and also due to lack of prior experience of formal schooling. An external formal schooling based child development demands considerable adjustment and replacement of many well tested household routines which a family with no prior experience may find extremely risky and costly. Nationwide action for implementation of "SSA" programme possibly worked as a collective low cost learning system for many households who hitherto remained on the periphery of mainstream learning and economic systems. It was not an individual household evaluation based behaviour but a collective acceptance of a new behaviour at societal level. Most such users rely on community based knowledge to make their decisions (Gherardi, \& Nicolini, 2000). Collective nature of this learning was one of the reasons for its fast diffusion.

Analysis of increase in the numbers of Primary and Middle schools and their enrolments over the two periods from 2001-02 to 2004-05 and from 2004-05 to 2007-08 indicated supply side push worked well for raising the enrolments in both the Primary and Middle schools in the first period from 2001-02 to 2004-05, but that for the second period from 2004-05 to 2007-08, the growth in enrolment of Primary schools dropped drastically because of significant cut back in growth of number of new Primary schools particularly the numbers of new Primary schools managed by the Government directly. It appeared quick harvest of a market coming out of conversion of latent demand into tangible transaction, required simultaneous macro level provisions for collective learning of users and micro level actions for prompt delivery of 
the promised services at low private cost to the users. Further, slow growth of privately managed Primary schools over the period from 2004-05 to 2007-08, even when number of Government managed schools were not growing fast, was indicative of non-scalability of privately managed schools for faster diffusion of elementary education. This showed in terms of speed of building new Primary schools, private management was a poor substitute to publicly managed school. Though, in terms of households' preference there was evidence of growing preference for privately managed Primary schools. The following three inter-related factors could be advanced as possible reasons for their slow growth.

Firstly, a privately managed Primary or a Middle school works like any other economic organization and its viability depends on availability of certain minimum number of students with capacity to bear its high tuition cost. Even a privately managed aided school has to raise a part of its operating budget from among its students. This potential for getting the required number of students is relatively high in urban areas but is quite low in rural areas and in states with poorly developed industrial economy. In many parts of India, social infrastructures like all weather road connectivity and transport facilities for commuting between different villages are very poor. Lack of all weather road connectivity and transport facilities could have worked against fast entry of private capital in Primary education space (Pal, 2010).

Apart from the entry barrier due to absence of social infrastructure, high price sensitivity of the households' demands for Primary school services could have played a role in affecting the growth of privately managed Primary schools. After the launch of "SSA" programme, much of the demands for class room space in Primary schools were induced demands from those segments of population who have had no or little participation in organized economic activities of the country where employments prospects were relatively stable and wage rates were high. Majority of these people worked either as agricultural labours or as marginal workers in rural informal sectors with highly unstable employment and wage. Most of these people lead a subsistence life. Such low level living make them highly sensitive to prices of all goods and services that they buy. As such their demands for Primary school services are expected to be very price elastic. A private entrepreneur planning to enter the business of offering education services may not find very many takers of her/ his services if the asking prices of such services are high. Only a low cost Government managed school could harvest such price sensitive demands. Similar high price sensitivities towards elementary education were found by Sabates, et al. (2013) in Bangladesh and by Geo-Jaja (2006) in Nigeria.

A third factor that possibly affected the growth of privately managed Government aided schools was the absence of manpower with leadership qualities for running the local private management committees that advise, liaise and supervise the running of these schools. Unlike a pure privately managed unaided school where the resource provider/ providers make all the decisions, a privately managed aided school requires the support of a locally built management committee which plans for its building construction, raises the required financial resources from different sources including that from the Governments and facilitates hiring of principal and other academic and administrative staffs. From the governance systems point of view, it is a decentralization of school management with considerable potential for improving the performance of a school and making it popular to the households. However, even such 
partial decentralization through locally formed management committee may fail if there is poor supply of leadership talent at such local levels as was noted by Mukundan \& Bray (2004) in their study in the Indian state of Kerala. Shortage of leadership skills has been found to be one of the critical factors for failure of school based management experiments of Thailand and Indonesia (De Grauwe, 2005; Gamage \& Sooksomchitra, 2004; Bjork, 2004). Highly fragmented social identity of Indians together with frequent bout of elections along political lines for various Government administrative bodies over-sensitize the citizens more on their differences from others and less on their needs to identify and work towards a common goal. Needless to add that, scope for finding wide difference in performance of such local school management committees across the country is quite high.

Our analysis of households' preference for school management for education of their children indicated growing preference for privately managed schools. Though, the user cost of schooling from a privately managed school was much higher than that from a Government managed schools. It was quite likely that because of the decentralized management, the reach of privately managed schools was much closer to households both in terms of their operational flexibilities as well as academic curriculum pacing. A privately managed school being free from the burden of complying with too many administrative rules designed by remotely located Government officials, could find ample space to differentiate its processes to suit the needs and preferences of its local clients. Among the many regulatory strings, rules on academic staffing and administrative personnel are the most stifling one with considerable potential to kill the innovative spirit of a school principal. All Government managed schools come under a common administrative rules in the area of staffing of academic and administrative personnel irrespective of their locations. Many such rules are often designed with good intentions but fail to reflect the ground realities of many schools located far from the metro cities. Many a time Governmental staffing rules prescribe strict enforcement of academic qualifications of teachers for a Government managed school. In many rural settings the supplies of educated manpower are very scarce and a school facing immediate superannuation or resignation of a teacher may have hard time getting a replacement even if the requirement of a new teacher is sent well in advance to the centralised recruitment authority of the state. Labour market conditions of urban and rural India are quite different. Though, by no means such rural-urban difference is unique for India. It is endemic in all developing countries. And, Even in U.S. there are urban areas where school staffing throws considerable challenge (Vegas, 2007).

A privately managed school being free from many such employment related regulations could manage staffing issues at a faster rate and at a much lower cost. Instead of going for the best candidate available in a market, it goes for a candidate who is available in its local market even if she/he has academic attainments less than what has been the standard followed by Government managed schools. Quality shortcoming if any, it manages through closer supervision and guidance by senior experienced teachers. Instead of searching for a teacher in a market where there are very few such well qualified teacher it searches for a potential teacher in a market where supply is reasonable and asking price is low. By following this policy it not only gets a candidate who suits its requirements well but also someone who is 
trainable to be more competent. This trainability quality along with prospect of growth in career is an important factor that ensures stability of a hired teacher. By choosing the pacing of the course curriculum that suits the strengths of its teachers and students, a privately managed school not only becomes an efficient user of locally available resources but also succeeds in getting better results by way of student performance. Government staffing rules willy-nilly make the Government managed schools an expensive venture which could turn into an unbearable budgetary burden on the backs of many industrially less developed states of India.

Further, because a privately run school particularly the unaided type has to raise its operating cost entirely from the students, it cannot but be more sensitive to number of students and their demands for academic inputs and learning. The average number of students per school for privately managed schools was much higher than that of the Government managed schools in both the Primary as well as in the Middle school stage. In board level examinations the performances of students from privately managed schools have been found to be consistently better than those from Government managed schools. In 2007-08 only $44.6 \%$ boys and $44.9 \%$ girls from Government managed schools scored $60 \%$ and above marks in Grade IV/V annual examination. In the same year $59.7 \%$ boys and $61.5 \%$ girls from privately managed schools scored 60\% and above marks in Grade IV/V examination. (Analytical Tables 2007-08). It was not an accident that average number of teachers per school was much higher in privately managed schools than those in Government managed schools. In 2007-08, the average number of teachers per school in Government managed Primary schools was just 2.81 while that in privately managed Primary school it was 4.47 . In the same year, the average number of teachers per school in Government managed Middle schools was 3.79 while that in privately managed Middle school this number was 6.79(Analytical Tables 2007-08). Though, part of the reasons for higher average number of teachers per school of privately managed schools was their urban setting. Most privately managed schools were located in urban areas of high population density and better developed markets for teachers. In 2007-08, as much as $80.5 \%$ of the privately managed elementary schools were located in urban areas (Analytical Tables 2007-08). However, even with this rider it cannot be denied that privately managed schools' higher sensitivity towards the needs of the students does pay on performance that matter most to households (Govinda \& Varghese, 1993). And, such favourable performance indicators of the privately managed schools vis-à-vis that of the publicly managed schools were not limited to India only. Jimenez, et al (1991) found such difference among eighth graders' performance in mathematics among privately and publicly managed schools in Dominican Republic. Jimenez, et al (1988) mentioned similar school management based performance difference in Thailand also. It was worth noting here that percentage of rural elementary school students who opted for privately managed schools were found to be rising every year. As per ASER survey report, in 2012 this percentage had reached 28.3\%. And, there were good number of states where more than $40 \%$ of the rural elementary school students were enrolled in privately managed schools (ASER, 2012). ASER survey is facilitated by Pratham, a non-Governmental organization established in 1994 to provide education to the slum children of Mumbai city. 
Thus we found on one side slow down of Governmental plan for launching of more number of new schools created supply side vacuum that pulled down the enrolment momentum of fresh students seriously on the other side with every passing year more and more young learners were migrating away from the Government managed schools to the privately managed schools. From the rapid fall in average number of students per schools in Government managed schools, it was quite obvious that even though as an instrument for shaping household attitude and behavior towards their children's learning, Government managed schools were quite effective but their processes did not appear sustainable as these types of schools were not very successful in delivering the promised services to the young learners. Privately managed schools because of competitive pressure from other neighborhood schools and because of high parental concern and attention towards children's performance, tend to improve their qualities as a learning institution fast over time.

\subsection{Conclusion}

This study attempted to understand if the Indian households' preferences for their children's education were shifting from Government managed schools to privately managed schools and whether the existing privately managed schooling facilities of India were scalable for a faster diffusion of elementary education across the country. It found in the prevailing state of the Indian economy and society, market for privately managed elementary education was growing however this model appeared non-scalable for mass education. The root cause of this non-scalability could be traced to high percentage of its population leading a subsistence life. Even low fee privately managed schools which are fast entering the rural schooling space have been found to be unavailable to large sections of the population because they could not afford to pay for their services (Harma, 2011). Considering that Indian households' perceptions for a pure state managed school's ability to provide quality learning to their children are falling fast, it appears for faster diffusion as well as for better learning outcome, there is need for more innovative approach towards financing and managing the elementary schools. Low cost elementary schools with poor staffing positions and equally poor local demands for academic performance are likely to hit the learning outcomes of children from poor families harder than those from economically better off families. Majority of the child learners from poor families are the first generation learners of their families. And, when a child from such a family is sent to a low cost state managed school with poor reputation of learner care, she/he may not get the required compensatory human capital support from home to make up for the loss due to poor teaching and mentorship support from the school. Such joint failure of a leaner's home and school could jeopardize her/his continued learning prospects quite seriously. No wonder, despite good success of "Sarva Shiksha Abhiyan" programme in raising the enrolment ratio of children from socially and economically disadvantaged groups of scheduled caste and tribes in India, their actual percentage in Secondary and Senior Secondary grades are yet to reach their population shares. In 2007-08, the percentages of Primary school children who were from the scheduled castes and scheduled tribes groups were $19.4 \%$ and $10.8 \%$ respectively. These percentages were better than their respective population shares. However, in Secondary stage, these percentage shares of learners from schedules castes and scheduled tribes were $15 \%$ and $6.2 \%$ respectively while 
that in the Senior secondary stages these percentages were $5.5 \%$ and $4.8 \%$ respectively (Selected Educational Statistics: 2007-08). Both voluntary withdrawal due to family economic compulsions and involuntary crowding out because of inadequate academic preparation take quite a heavy toll on the school participation prospects of those young learners.

On the theoretical side by identifying the important role played by the state managed low cost schools in creating an affordable learning environment and yet a situation of fast migration of children from state managed to privately managed schools, the study takes the contemporary debate on state vs non- state providers of education and its effects on access and equity a step forward (Bangay \& Latham, 2013; Woodhead et all, 2013).

\section{References}

ASER. (2012). Annual Status of Education Report 2012 (Rural) Finding, ASER Centre. Retrieved October 11, 2013 from http://www.asercentre.org/

Analytical Tables 2004-05. Retrieved March 29, 2011 from http:// www.dise.in/AR.htm

Analytical Tables 2007-08. Retrieved March 29, 2011 from http:// www.dise.in/AR.htm

Bangay, Colin \& Latham, Michal. (2013). Are we asking the right question? Moving beyond the state vs non-state provider debate: reflection and case study from India. International Journal of Educational Development, 33(3), 244-52. http://dx.doi.org/10.1016/ijedudev.2012.09.004

Bjork, Christopher. (2004). Decentralization in education, institutional culture and teacher autonomy in Indonesia. International Review of Education, 50, 245-262.

De Grauwe, Anton. (2005). Improving the quality of education through school based management: Learning from international experience. Review of education, 51, 269-287.

Dixon, Pauline \& Tooley, James. (2005). The Regulation of Private schools serving low-income families in Andhra Pradesh, India. The Review of Austrian Economics, 18(1), 29-55.

Gamage, David T., \& Sooksomchitra, Pacharapimon. (2004). Decentralization and School based management in Thailand. International Review of Education, 50, 289-305.

Geo-Jaja, Macleans A. (2006). Educational decentralization, public spending and social justice in Nigeria. International Review of Education, 52, 125-148.

Gherardi, Sylvia, \& Nicolini, Divide. (2000). The Organizational Learning of Safety in Communities of Practice. Journal of Management Inquiry, 9(1), 7-18.

Govinda, R., \& Varghese, N. V. (1993). Quality of Primary schooling in India: A case study of Madhya Pradesh. Paris: International Institute of Educational Planning.

Government of India, New Delhi. (2000). Sarva Shiksha Abhiyan: Programme for Universal 
Elementary Education in India, Department of Elementary Education and Literacy, MHRD; Retrieved March 29, 2011 from http://www.educationforallinindia.com/ssa.htm

Government of India. (2010). Education in India: 2007-08, Ministry of Statistics and Programme Implementation, 2010, Participation and Expenditure: NSS 64th Round, New Delhi: National Sample Survey Office.

Goyal, Sangeeta. (2007). Learning Achievement in India: A study of Primary Education in Rajasthan. South Asian Human Development. Washington D.C: The World Bank.

Hanson, E. Mark (1998). Strategies of educational decentralization: Key questions and core issues. Journal of Educational Administration, 36(2), 111-128.

Harma, Joanna. (2011). Low cost private schooling in India: Is it pro poor or equitable? International journal of educational development, 31(4), 350-56. http://dx.doi.org/10.1016/j.ijedydev.2011.01.003

Hawkins, John N. (2000). Centralization, decentralization, recentralization: Education reforms in China. Journal of Educational Administration, 38(5), 442-454.

Ikoya, Peter O. (2008). Centralization and decentralization of schools' physical facilities management in Nigeria. Journal of Educational Administration, 46(5), 630-649.

Jimenez, Emmanuel, Lockhead, Marlaine \& Wattanawaha, N. (1988). The relative efficiency of private and public schools: The case of Thailand. The World Bank Economic Review, 2(2), 139-164. http://dx.doi.org/10.1093/wber/22.139

Jimenez, Emmanuel, Lockhead, Marlaine, Luna, Edward, \& Paqueo, Vincente (1991). School effects and cost for private and public schools in the Dominican Republic. International journal of educational research, 15(5), 393-410. http://dx.doi.org/10.1016/0883-0355(91)90021-j

Kingdon, Geeta. (1996). The Quality and Efficiency of Private and Public Education: A Case study of Urban India. Oxford Bulletin of Economics and Statistics, 58(1), 57-82.

Lo, William Yat Wai \& Gu, Ja Oek. (2008). Reforming school governance in Taiwan and South Korea: empowerment and autonomization in School based management. International Journal of Education Management, 22(6), 506-526.

Mok, Ka-Ho. (1999). Education and the market place in Hong Kong and Mainland China. Higher education, 37, 133-158.

Mukundan, Mullikotu-Veettil \& Bray, Mark. (2004). The decentralization in Kerala State, India: Rhetoric and reality. International Review of Education, 50, 223-243.

Muta, Hiromutsu. (2000). Deregulation and decentralization of education in Japan. Journal of Educational Administration, 38(5), 455-467.

Ornelas, Carlos. (2000). The Politics of the Educational Decentralization in Mexico. Journal of Educational Administration, 38(5), 426-441. 
Pal, Sarmistha. (2010). Public infrastructure, location of private schools and primary school attainment in an emerging economy. Economics of Education Review, 29, 783-794. http://dx.doi.org/101016/j.econ.edurev.2010.02.002

Sabates, Ricardo, Hossain, Altaf \& Lewin, Keith M. (2013). School dropout in Bangladesh: Insight using panel data. International Journal of Educational Development, 33(3), 225-232.

Schiefelbein, Ernesto and Schiefelbein, Paulina. (2000). Three decentralization strategies in two decades: Chile 1981-2000. Journal of Educational Administration, 38(5), 412-425.

Selected Educational Statistics: MHRD, 2004-05, Retrieved March 29, 2011 from http://www.educationforallinindia.com/ses.html

Selected Educational Statistics: 2005-06, All India, Time-Series, Retrieved March 29, 2011 from http://www.educationforallinindia.com/ses.html

Selected Educational Statistics: 2006-07, State-wise, All Tables, retrieved March 29, 2011 from http://www.educationforallinindia.com/ses.html

Selected Educational Statistics: 2007-08, Retrieved March 29, 2011 from http://www.educationforallinindia.com/ses.html

Tang, Kwok-Chun, \& Bray, Mark. (2000). Colonial models and the evolution of education system: Centralization and decentralization in Hong-Kong and Macao. Journal of Educational Administration, 38(5), 408-485.

Vegas, Emiliana. (2007). Teacher labor markets in developing countries. The Future of Children, 17(1), 219-232.

Winkler, D. (1993). Fiscal decentralization and accountability in education: Experience in four countries. In Hannaway, J. \& Carnoy, M. (Eds) Decentralization and School improvement (pp 104-109), San Francisco, CA: Jossey-Bass.

Woodhead, Martin, Frost, Melanie \& James, Zoe. (2013). Does growth in private schooling contribute to education for all? Evidence from a longitudinal two cohorts study in Andhra Pradesh, India. International Journal of Educational Development, 33(1), 65-73. http://dx.doi.org/10.1016/j.ijedudev.2012.02.005

\section{Copyright Disclaimer}

Copyright reserved by the author(s).

This article is an open-access article distributed under the terms and conditions of the Creative Commons Attribution license (http://creativecommons.org/licenses/by/3.0/). 